\title{
The Implication of the Strategic Implementation Style and Middle Management Effort in Public Organization
} Strategic Management Implementation and Its Organizational Performance

\author{
Bienmali Kombate \\ College of Public Administration, Huazhong University of Science and Technology \\ Address: 1037 LouYu Road, Huazhong University of Science and Technology, Hongshan \\ District, Wuhan, Hubei 430074, China \\ E-mail: bienmali41@yahoo.com

\begin{abstract}
Muganga Emmanuel
College of Public Administration, Huazhong University of Science and Technology Address: 1037 LouYu Road, Huazhong University of Science and Technology, Hongshan District, Wuhan, Hubei 430074, China

E-mail: mugangaemma@yahoo.com
\end{abstract}

\begin{abstract}
Kouadio Konan Richard
School of Manahement, Huazhong University of Science and Technology

Address: 1037 LouYu Road, Huazhong University of Science and Technology, Hongshan District, Wuhan, Hubei 430074, China

E-mail: konanrichard01@yahoo.fr
\end{abstract}

Received: Dec. 13, 2020 Accepted: Dec. 30, 2020 Online published: Jan. 3, 2021

doi:10.5296/jpag.v11i1.18150 URL: https://doi.org/10.5296/jpag.v11i1.18150

\begin{abstract}
Strategic management implementation in public sector study has nowadays become the most commonly researched area among public administration scholars and researchers. However,
\end{abstract}


to the best of our knowledge, there has been no attempt to investigate the influence of the implementation style and the middle management on the Strategic Management Implementation (SMI) and organizational performance (OP). There is a paucity of studies that have been undertaken in developing countries. This study aims to fulfil this research gap, investigated in the moderated mediation effect of the combination of the implementation style and middle management effort in the relationship between SMI and OP. The study data was collected on a sample of 468 public managers in the Togolese central government organizations. The findings show that public organisations that opt for logical implementation style in its program implementation result in a non-significant estimate at the mean and 1SD below the middle management effort (W). However, in the organization that applies incremental implementation style in its program implementation, the estimates at mean, 1SD below and 1SD above the mean of the $\mathrm{W}$ are all statistically significant. Developing country public sector organisations characterized by traditional bureaucracy and lack of administrative reform program implementation that opt for logical implementation style will likely decrease performance.

Keywords: strategic management implementation, logical implementation style, incremental implementation style, organizational performance, and moderated mediation

\section{Introduction}

Strategic management implementation is a disciplinary root of the most popular theories and models in which direction is constructed on the strategic positioning school. Caves et al. (1980); Porter (2008)added the three strategic typologies, such as: "cost leadership, differentiation, and focus strategy"(Ferlie and Ongaro 2015). These generic strategies determine if an organization aims to produce or to distribute a product or service at the lowest price (cost), adding value to the product or service (differentiation), or concentrating on meeting the needs of a particular customer group (focus). Such kind of strategy apply in the private sector often not always helpful because of its overwhelming emphasis on achieving market share and growth through competition, fundamental elements lacking in the PSM context. However, recently strategic positioning has received more attention in the lights of NPM, and the ideas of creating more market-like competitions have relied on strategic positioning. Rosenberg Hansen and Ferlie (2016), in their research, suggest that there are further possibilities for applying theories about strategic positioning (an outward-looking perspective) in public organizations, especially when rating highly on the three core dimensions of administrative autonomy, performance-based budgets, and market like competition. Johanson (2009) added that in the public context, the emphasis on cost is any expanded characteristics of competition, e.g., organization may define additional features of service quality (safety measures or environmentally friendly emission standards in competitive tendering in transportation).

Except for the user of Miles et al. (1978) the fonder of strategic typologies, few scholars among those aiming at SMI and public administration researches such as Andrews et al. (2005), Andrews, Boyne, and Walker (2006), Andrews et al. (2008); Andrews et al. (2007), Andrews et al. (2009), Ferlie and Ongaro (2015), and Höglund (2015) take an interest in exploring theories 
within this direction. However, few of these scholars had paid attention to narrow their investigation on the impact of public organization strategic management on its organizational performance.

\section{Relationship Between Strategy Management Implementation and Public Organizational Performance}

SMI and OP are inextricably interconnected. This relationship is undeniable because organizational objectives are shaped as part of its strategic management implementation process (Abdel-maksoud 2015; Pollanen et al. 2017). Bryson $(2012,2018)$ defined Strategic management implementation as intentional and disciplined efforts to produce ultimate decisions and actions that shape and guide what the organization is, what it does, and why. It gets complete success by being cascaded down after the organization as an entire, to the sub-units, then to their sub-units, until ultimately, they are allocated, often as fragments of the whole, to distinct workforces and is done over the process of individual employee goal setting or objective setting through the organizational performance planning phase of strategic management. Grounding on this, Schaefer \& Guenther (2016) and Bryson (2012) concluded in their studies that organizational performance is a critical component of strategic management implementation.

Although framing a coherent strategy is a tough task for the management team, it is even more difficult to implement this strategy and work across the organization (Hrebiniak 2006; de Oliveira, Carneiro, and Esteves 2019). Effective strategy management implementation must (1) spell out the future track, (2) propose internal action approaches, (3) make the appropriate choices and priorities, (4) effectively manage organizational changes and uncertainties in the external environment, (5) develop the teamwork and capability based on resources, procedures and people and (6) develop effective strategies to increase organizational performance (Cole 2004). SMI requires to categorizes important actions, decisions, and relationships needed to complete the task. According to Mintzberg (2007), organizational SMI follows six management function including (1) the development of effective organizational structures, (2) ensure enough resources to support the process, (3) create an internal support system, (4) establish rewards and incentives that align with the strategic goals, (5) forming a corporate culture to adapt to the strategy, and (6) provide strategic leadership. Hence, organizational performance generally is typical to the particular organization, as it depends on the strategy management choices (Desmidt and George 2016; Steers 1975; Venkatraman and Ramanujam 1986, 1987).

Besides, successful SMI depends on the chosen strategy implementation style (rational, incremental, and logical-incremental implementation) and middle management's efforts in the implementation process. Inkpen and Choudhury's (1995) concept of "strategy absence" suggests that organizations may have a perceptible strategy implementation style. In such organizations, there is no self-evident or preferred routine for implementing strategies. Neither a rational nor incremental implementation style is a prioritized nor a coherent attempt to combine these approaches. The lack of a clear approach to implementing the strategy may be associated with poor performance, as those involved in introducing new practices have 
few processes and procedures to appeal or not be encouraged to participate in decision-making on the ground. Hickson, Miller, and Wilson (2003) indicate that the implementation of decisions that are neither "experience-based" nor "readiness-based" may be associated with poorer performance than those approaching one or the other approaches. Therefore, the relationship between particular strategy management and its impact on the particular organizational performance relies on its implementation style.

Hypothesis 1: Public organizations that implement its program without following a specific implementation style will likely decrease in performance

\section{Theories of Logical and Incremental Implementation Styles}

The two implementation styles, such as rational or logical and incremental or ad hoc developed by strategic decision-making theories, are mostly applied in public sector researchers. The Incremental implementation style refers to relatively minor adjustments to the general pattern of things in pre-existing systems, hierarchies, models, products, services, and processes. Dosi (1982) refers to the incremental implementation style as technological progress, although the logical implementation style involves the construction of skills that can lead to a paradigm shift. On the one hand, incremental implementation style can imply a change in organizing the organization's additional resources, creating and developing new versions of a product or service. On the other hand, a logical implementation style includes applying a combination of new technologies and knowledge (Myers 2005).

A theoretical framework that is still relevant today is that of C. M. Christensen (2006), which addresses the terms of support and disruptive SMI, in which sustained SMI improves value for the customer, offering the maximization of organizational performance. Moreover, the organization SMI choice of incremental or radical implementation styles implies a reform of the organizations, their structure, and the nature of their products or services. Additionally, to continue making small improvements, organizations also manage to adapt to the logical implementation style in their SMI characterized by a high degree of new knowledge and uncertainty (Dewar and Dutton 1986; Henderson and Clark 1990; Leifer et al. 2000). An organization's ability to seek and explore to adapt over time to changing conditions is defined as ambidextrous organizations (Wu 2017). The balancing act of organizations guarantees short-term Efficiency and long-term Efficiency (March 1991).

The Oslo Manual 2010 classifies the incremental implementation style as "insignificant" changes in products and processes or that do not involve a sufficient degree of novelty (Gault 2010). Popadiuk and Choo (2006) detail the differences between incremental and logical implementation styles from different perspectives. An incremental implementation style happens in the short term. Follow a development path of six to 24 months. It is carried out step by step, from the conception of the strategic intent to its full implementation. It is the merchandise of generations of ideas, and recognizing opportunities with continuous incremental improvements, formal and established processes. Logical implementation style is approached from the perspective of existing strategy capabilities, being completely renewed and replaced with new skills, while competitive benchmarking activities and cooperation with stakeholders focus on incremental implementation styles (Atuahene-Gima 2005). 
Cooperation between organizations is essential to improving organizational performance (Belderbos, Carree, and Lokshin 2004).

The theories of logical implementation style and incremental implementation style are also discussed from the perspective of knowledge creation and are classified in the degree of novelty in research and development (Popadiuk and Choo 2006). Several researchers, including Andrews, Beynon, \& Genc (2017) and Parsa (1999), argued that the rational or logical implementation style has a positive impact on organizational performance in term of effectiveness, efficiency, and equity and prioritizes getting employees to follow the right processes for familiarizing new strategies. However, the opposite is observed in the organization that chose the incremental implementation style in its SMI (Andrews et al. 2017) and revealed the fluid nature of transformation management and the importance of motivating and support the strategies change during their implementation (Hussey 1999).

Hypothesis 2: The logical implementation style mediates the relationship between SMI and public OP.

In their book titled Exploring strategic change, Balogun \& Hailey (2008)reported that around $70 \%$ of organizations that applied incremental implementation style in their new strategy management implementation failed. Incremental implementation style might also indicate an ultimate lack of a valid charter on how to successfully implement and manage organizational change because what is presently available is incompatible theories and approaches, which generally do not have empirical evidence and are often based on unnecessary assumptions about the nature of management contemporary organizational change.

Hypothesis 3: The incremental implementation style mediates the relationship between SMI and public OP; however, the effect is weaker than in $\mathrm{H} 2$

\section{Theory of Middle Management in Strategy Management Implementation}

In the SMI, the middle manager guiding the workforce, facilitating development and collective participation, ensuring implementation, inducing team members to the behaviours expected of disciples, actors, and agents in participating in change. The middle manager's role as a change agent seems multidimensional and conflicting (Allard-Poesi 2015). Indeed, a top manager is usually acknowledged carefully with proper strategies, making it less probable that different initiatives will be proposed. As an alternative to the strategy's top-down rational implementation style, Burgelman's (1994) vision of the evolutionary process categorizes middle managers as those who regularly recognize the need for divergence and initiate changes. Middle managers function as safeguards between initiatives at the operational level and management review, given that resources and attention for agendas differ from official paths (Floyd and Wooldridge 1992). Burgelman (1994) demonstrates how the development of necessary abilities and formal strategy changes results from middle managers' influence. Once "the time is right," middle managers defend top management initiatives; however, the plans become the seeds of new capabilities if approved.

Middle managers are not mere extras in change management operations, but real actors with room for negotiation, authors who co-construct the meaning of change (Balogun and Johnson 
2004). Balogun and Johnson highlighted the importance of middle management in the SMI in their work by making sense of his role during a top-down shift initiated by top management. Responsible for implementing and developing the operational details of a new structure (semi-autonomous teams), middle managers are objects of change and actors in its implementation. Qualitative analysis shows that recipients of change create change: they determine its outcome through social processes of interaction and the meanings they develop. This research shows that it is essential to understand and be aware of change recipients' multiple interpretations during organizational change.

Following this foundational work, Rouleau and Balogun (2011) seek to understand better how middle managers underwrite strategically to enhance the OP by examining how they "activate" the strategic roles dedicated to them. The authors develop a framework that shows two interrelated discursive activities:

- Lead the conversation, exchanges: This activity refers to a constructive verbal exchange that attempts to reconcile divergent demands and interests from higher and operational levels, or different parts of the same organization: using the right vocabulary, building and delivering the right message, knowing what to say to different stakeholder groups, contact other stakeholders.

- Configure the scene: This activity refers to the ability of middle managers to unite people around a change project to make sense of it and build an alliance concerning this change, although the reasons are given in favour of the change differ and are specific to each person by knowing whom to influence, identifying the appropriate means of communication for the different interest groups, building networks to mobilize them later.

This activity of discursive "staging" refers to the effect of power in the construction of meaning, by which some voices have more influence than others. The construction of meaning corresponds to the ability to act politically and activate a "systemic power" (Lawrence, Ashford, and Dent 2006). To act politically, middle managers need to socialize in their context of action to understand verbal representations and socio-cultural systems.

These two activities are essential for middle managers to fulfil their strategic roles and make sense of change. These activities are reinforced by administrators' capacity to rely on symbolic and verbal representations of the socio-cultural system.

\subsection{The Effect of the Combination of MI and W in the Relationship Between SMI and OP}

Despite the predominance of transformation efforts in the public sector, many public organizations are not achieving the desired results in the organizations that opted for logical implementation style in their SMI (Higgs and Rowland 2010; Kalyal et al. 2010; McCarthy et al. 2013; McTaggart and O'Flynn 2015). Failure is often attributed to employee resistance to change (Coram and Burnes 2001; Piderit 2000) or cynicism towards change efforts (Buick et al. 2015; Thundiyil 2015), which involves a by-product of change that leads top managers in their SMI with logical implementation style to perceive employees as barriers to change (Ford, Ford, and D'Amelio 2008; De Jager 2001; Piderit 2000). However, others describe 
resistance to change in SMI that applying logical implementation style as an essential resource for change success. It provides an opportunity for feedback that can help drive change (Ford, Ford, and D'Amelio 2008; De Jager 2001; Piderit 2000). Both sides show the importance of effective change management (Ford, Ford, and D'Amelio 2008), including managers who intervene in change (Balogun 2003), managing the organizational operation during its SMI process (Huy 2002). It has been argued that middle managers can be a source of success for SMI, which opted for the logical implementation style by overcoming employee resistance (Balogun 2003; Huy 2002). They may have the ability to achieve SMI success, manage and effectively implement change in a way that influences positive attitudes toward change (Floyd and Wooldridge 1994; Sheehan 2005).

The middle managers in the public sector organization SMI manage the internal operation by influencing, preventing, or reducing resistance and examining how to shape, support, and communicate change. In the current views on managing the organizational operation, middle managers' potential role in SMI that applying logical implementation style is the centrality of organizational support in strengthening his influence. Qualitative research results have highlighted the middle managers' central role in managing the organizational operation to better implement change. The idea of using middle managers as active change agents to help shape and reflect on change with employees has excellent potential, and the value gains require actively managed organizational support to develop mid-level change management capabilities. It implies that middle managers, as change agents, during the SMI process that opted for logical implementation style, should exhibit their ability to manage the organizational operation, which is particularly important to improve the OP.

Hypothesis 2a: a public organization that combines logical implementation style and middle management efforts in its SMI will generate a positive OP

\subsection{The Effect of the Combination of M2 and W in the Relationship Between SMI and OP}

If we accept SMI that applying incremental implementation style as an ongoing activity at the internal level, where people interact and make sense of their social reality, participation and dialogue, collective reflection, and knowledge building are essential. Even small changes can have severe consequences due to self-reinforcing feedback loops and social media relationships (Boonstra, 2004; Madjar, Greenberg, and Chen 2011; Tichy and Bennis 2007). Rouleau and Balogun (2008) argue that middle managers in an organization that opt for incremental implementation style in its SMI have to engage in dialogue and networks essential to their strategic thinking role. They also indicated that these two activities draw on the practical semantic and socio-cultural knowledge of middle managers, enabling them to involve people in changes in their daily activities. This view is also corroborated by Huy's earlier study of organizational change in a large US utility (Huy, 2001). He found that middle managers in an organization that is applying incremental implementation styles, who take the time to build strong networks and build trust and authority, are better placed to 'sell' change to the rest of the organization, mostly if they have done such a subtle and sure way.

A large body of research shows that middle managers in the organization SMI that chose the incremental implementation style have every opportunity to manage the organizational 
operation by influencing the perceptions, attitudes, and beliefs of their employees to strengthen their commitment to their organization's goals and help them approach change with enthusiasm rather than with resistance leading to enhance the OP (Bass 1985; Conger and Kanungo 1987; Shamir, House, and Arthur 1993).

Hypothesis 3a: a public organization that combines incremental implementation style and middle management efforts in its SMI will generate a positive OP; however, the effect will be weaker than in $\mathrm{H} 2 \mathrm{a}$

\section{Methodology}

There are two distinct methodological approaches, including quantitative and qualitative. In comparison, quantitative research adopts a research strategy that explores phenomena by collecting and analyzing numerical or quantitative data to consider social reality objectively. (Bryman 2011) argue that quantitative methods integrate objectivist ontology and positivist epistemology practices and principles. Self-completion questionnaires, structured interviews, structured observation and psychological testing, are the most commonly used quantitative research methods (Grimshaw et al. 2004). The most commonly applied qualitative research methods are unstructured interviews, participant observation, and personal observer records (Grimshaw et al. 2004). Thus, after considering both methodologies' implications, this study chose to use a quantitative methods approach.

\subsection{Study Context: Togolese Public Sector}

The need for strategy and strategic management implementation in the Togolese public sector has never been more urgent and legitimate than in recent years (Poister, Pitts, and Hamilton Edwards 2010). Increasing financial and social pressures push the Togolese executive and public organizations to rethink how they operate and structure their actions according to clearly defined goals and priorities. Thus the Togolese Government's new strategic management plan called Programme Nationale de Developpement (PND), on which this study is grounded, aimed at the modernized public organization by strengthening their abilities in delivering public services delivery. Nevertheless, and if SMI emerges today as a practice primarily institutionalized in a large number of Togolese public organizations (Lewis, Williams, and Franklin 2008), it still raises several questions about its ability to improve public organization performance (Andrews et al. 2007) and produce change (Mosca et al. 2011). Poister et al. (2010) hence note the absence of studies that clearly show the positive influence of SMI on public organizations' performance. It is also a separation between SMI on the one hand and the choice of implementation style and middle management in the implementation process. These observations lead us to question the legitimacy of strategy in public settings and the types of approaches applied to it.

The Togolese Public organization has considerable administrative and financial autonomy and is a multi-purpose government providing public services. The study aimed to investigate the relationship between SMI and the public OP and the implication of the combination of the implementation style and middle management efforts in the implementation process. A survey questionnaire was used to collect data from the public managers on their viewpoints 
on relevant concepts.

\subsection{Data Collection and Material}

This study's data was collected through the structural questionnaires adopted from Andrews et al. (2017), Salkic (2014), Judge \& Stahl (1995) and (Genc 2017). For cross-cultural research (Brislin 1970), the questionnaires were initially translated into French and distributed to a small sample of 30 participants. This pilot study enabled us to re-edit and fix the questionnaires. The final version of the questionnaires was joined together with the personal statement that explains the research purpose, and the two letters of permission. Few of the respondents accepted an appointment to fill the questionnaires. In many cases, the secretaries or staff members assisted us by collecting the questionnaires and, in turn handing to the targeted respondents. A permanent contact through the phone with this third party was set for following up and updating till the successful completion.

Four hundred sixty-eight questionnaires were filled and returned to us out of 650 questionnaires distributed. The study population included public managers in eight (8) ministries, including the ministry of planning, the ministry of public work, the ministry of high education and research, the ministry of technical education and professional training, the ministry of transport and infrastructure, the ministry of primary education, the ministry of commerce, and the ministry of territorial administration, decentralization, and local authorities.

\section{Findings and Discussion}

\subsection{Items Reliabilities}

The statistics result in table 5.12 shows Cronbach's Alpha $=.891$, which indicated that there is a higher correlation ranked among the items. Additionally, the value of Cronbach's Alpha $=.891$ is higher than .70 , which means that the result is acceptable (Nunnaly 1978). Thus the study concluded that all items used in this study are consistent and measure the same thing.

Table 1. Reliability Statistics of all Item

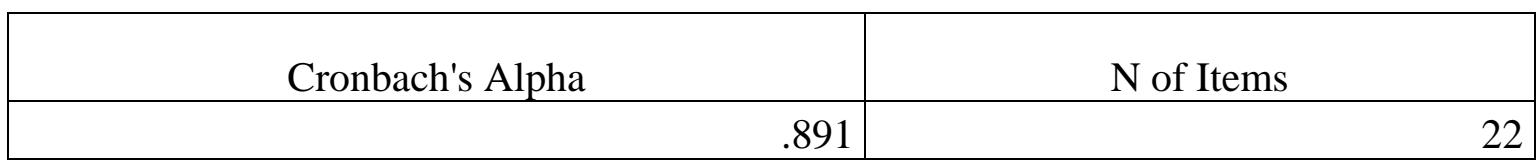

Source: author data field-2020

\subsection{Construct Reliability}

Looking at the individual Cronbach's Alpha coefficients results show in tables 2. all items score a Cronbach's Alpha coefficient higher .8. Therefore, the study concluded that the internal consistency of the scale elements is good. 
Table 2. Items reliability of Implementation style (M1 and M2)

\begin{tabular}{|l|r|r|r|r|}
\hline & $\begin{array}{c}\text { Scale Mean } \\
\text { if Item } \\
\text { Deleted }\end{array}$ & $\begin{array}{c}\text { Scale } \\
\text { Variance if } \\
\text { Item Deleted }\end{array}$ & $\begin{array}{c}\text { Corrected } \\
\text { Item-Total } \\
\text { Correlation }\end{array}$ & $\begin{array}{c}\text { Cronbach's } \\
\text { Alpha if } \\
\text { Item Deleted }\end{array}$ \\
\hline Defined Tasks & 77.61 & 126.007 & .427 & .888 \\
\hline Weekly - Monthly Plans & 77.87 & 118.543 & .628 & .882 \\
\hline Precise Procedures & 77.59 & 122.298 & .580 & .884 \\
\hline Regularly Review & 78.12 & 128.217 & .331 & .887 \\
\hline Piloting Strategies & 77.86 & 121.882 & .575 & .891 \\
\hline Gradually Implement & 77.68 & 127.948 & .414 & .884 \\
\hline Amend Strategies & 77.78 & 125.834 & .541 & .888 \\
\hline Continual Changes & 77.98 & 135.357 & .016 & .896 \\
\hline $\begin{array}{l}\text { Similar Way } \\
\text { Ongoing Adjustment }\end{array}$ & 77.57 & 130.550 & .317 & .891 \\
\hline $\begin{array}{l}\text { The quality of outputs, e.g., } \\
\text { reliability of service delivery } \\
\text { (OP1) }\end{array}$ & 77.45 & 120.317 & .670 & .881 \\
\hline $\begin{array}{l}\text { The quantity (number of outputs), } \\
\text { e.g., the volume of service } \\
\text { delivery (OP2) }\end{array}$ & 77.68 & 123.368 & .555 & .885 \\
\hline $\begin{array}{l}\text { The efficiency (value of Money), } \\
\text { e.g., cost per unit of service } \\
\text { delivery (OP3) }\end{array}$ & 77.55 & 126.256 & .502 & .886 \\
\hline $\begin{array}{l}\text { The effectiveness. e.g., whether } \\
\text { your objectives were achieved } \\
\text { (OP4) }\end{array}$ & 77.98 & 124.421 & .509 & .886 \\
\hline Citizen satisfaction (OP5) & & & & \\
\hline $\begin{array}{l}\text { The equity, e.g., services, are } \\
\text { equitably distributed amongst } \\
\text { citizens (OP6) }\end{array}$ & 77.29 & 124.838 & .609 & \\
\hline
\end{tabular}

Source: author data field-2020

\subsection{Model Fit}

This section presents the test of model fit's statistics results using Structural Equation Modeling (SEM), a popular data analysis technique with researchers in various disciplines. However, the question of which theoretical model best represents the data is still a debate. With so many adjustment indexes available and no agreement on which index to report, it became confusing. Besides, the threshold value of the existing index has not been agreed upon. In this work, to check our model fitness, we applied the fit indices for SEM, which researchers most often use in social sciences, introduced by Hooper, Coughlan, and Mullen (2008)Chi-square, GFI, AGFI, CFI, AGFI, and RMSEA. 
The results show in figure 1 that all the fit indices indicate a good fit; therefore, the study concluded that the data fit with the model.
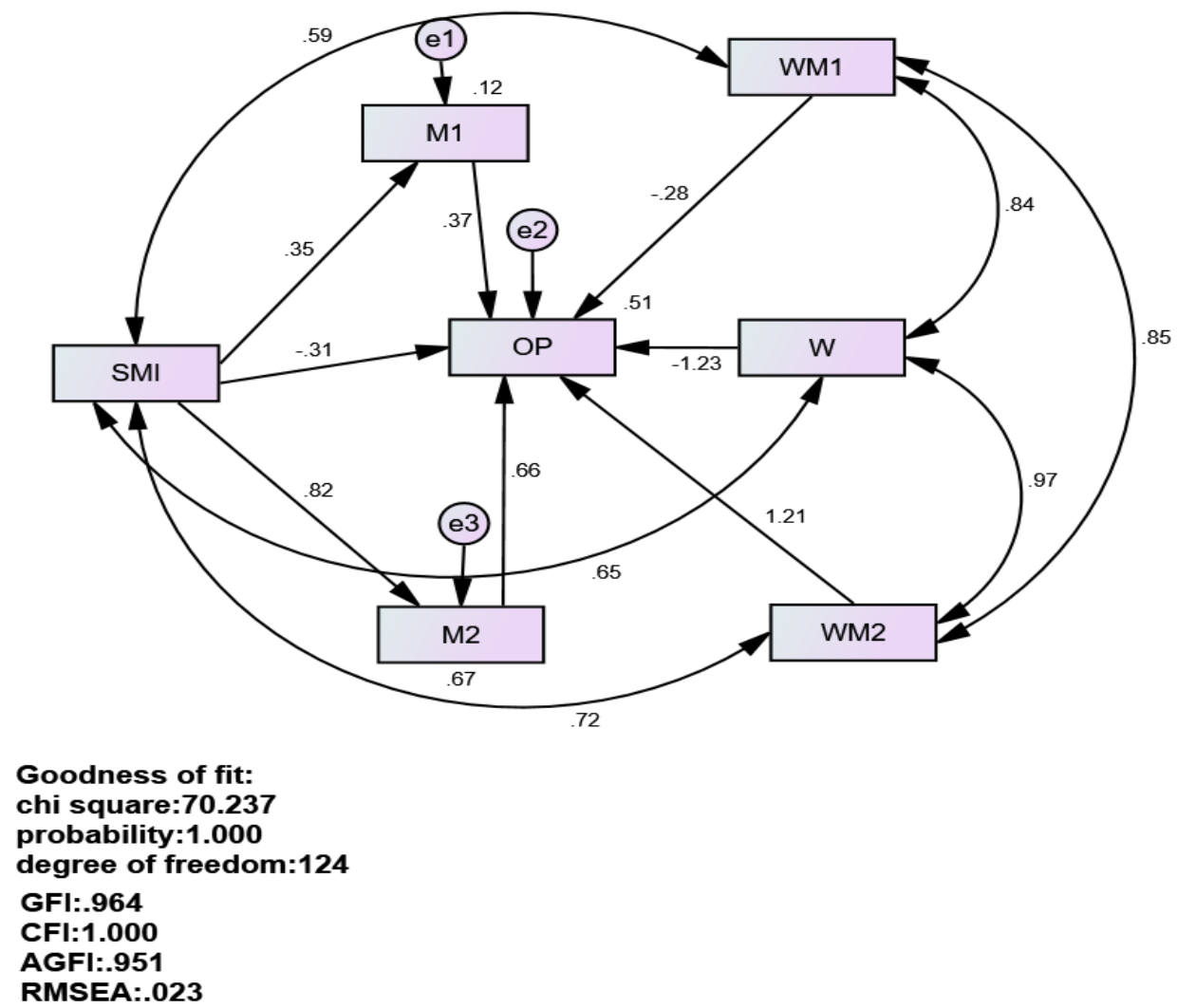

Source: author data field-2020

\subsection{The Direct Relationship between SMI and OP}

The results show in table 3 that the coefficient that defines SMI and OP's direct effect when the mediator variables M1, M2, and M3 are introduced in the model is $C^{\prime}:-.31<0$. This means that the direct effect of SMI on OP is negative

Table 3. Standardized Direct Effects (Group number 1 - Default model)

\begin{tabular}{|l|rrrrrr|}
\hline & WM2 & W & WM1 & SMI & M2 & M1 \\
\hline M2 & .000 & .000 & .000 & .820 & .000 & .000 \\
M1 & .000 & .000 & .000 & .346 & .000 & .000 \\
OP & 1.211 & -1.235 & -.281 & -.308 & .663 & .374 \\
\hline
\end{tabular}

Source: author data field-2020 


\section{Testing the Hypothesis one}

The results show in table 4 that the value of the Critical Ratio of the regression weight that defines the direct effect of SMI on OP is C.R.: $|-3.415|>1.96$, and present a two-tailed significance at the at p-value p: $5 \%$. Thus the null hypothesis is rejected (Gao, Mokhtarian \& Johnston, 2008). Consequently, the study concluded that the direct effect of SMI on OP is negative $C^{\prime}:-.31$ and significant at 5\% two-tailed. Hence hypothesis 1 is accepted. The public organization that implements its program without a specific implementation style will likely decrease in its organizational performance(OP). i.e., when the SMI process goes up by 1 , the OP will go down by .31 .

Table 4. Regression Weights: (Group number 1 - Default model)

\begin{tabular}{|c|c|c|c|c|c|c|c|}
\hline & & & Estimate & S.E. & C.R. & $\mathrm{P}$ & Label \\
\hline M1 & $<--$ & SMI & .362 & .068 & 5.363 & $* * *$ & $\mathrm{a}$ \\
\hline M2 & $<--$. & SMI & 2.577 & .124 & 20.798 & $* * *$ & $\mathrm{c}$ \\
\hline $\mathrm{OP}$ & $<--$ & SMI & -.261 & .077 & -3.415 & $* * *$ & $\mathrm{~b}$ \\
\hline $\mathrm{OP}$ & $<--$ & M1 & .304 & .172 & 1.764 & $* * *$ & d \\
\hline $\mathrm{OP}$ & $<---$ & M2 & .179 & .059 & 3.037 & .002 & e \\
\hline OP & $<--$ & WM1 & -.012 & .015 & -.767 & $* * *$ & $\mathrm{f}$ \\
\hline OP & $<--$ & W & -.850 & .181 & -4.699 & $* * *$ & g \\
\hline OP & $<--$ & WM2 & .013 & .004 & 3.452 & $* * *$ & $\mathrm{~h}$ \\
\hline
\end{tabular}

Source: author data field-2020

The finding supports existing literature, including (Adams et al. 1985; Al-Ghamdi 1998; Beer and Eisenstat 2000). Researcher Hickson, Miller, and Wilson's (2003) studies finding also show that the implementation of a program that is neither "experience-based" nor "readiness-based" might lead the organization to decrease its organizational performance. The public organization program implementation should not only be a mere structured program; however, its implementation should have a predefined style which includes the details of daily, weekly, and monthly activities with a specific implementation method either relying on the previous experience, radical change, or on dual implementation style to drive their activities (Inkpen and Choudhury 1995). SMI process does not end when the organization decides what strategy to pursue; however, it must be translated into a series of strategic thoughts and actions (Naumann et al., 2011). Thompson and (Strickland, Thompson, and Gamble 2001) concluded that an organization SMI must have proper structures, clear and contributory implementation style, and systems that ensure that the organization behaves in a cohesive rather than fragmented manner.

An effective SMI that enhances the OP needs to be translated into more detailed policies and procedures that can be understood at the functional level (Candido and Santos 2015).

To achieve the organizational outcome, its SMI should comprise a series of decisions, actions, and steps that involve multiple resources. This finding also supports Alexander (1985) conclusion that SMI associated with poor OP is due to ineffective implementation activities because of the non define implementation style. This finding also supports Pella n.d. (1998) conclusion, who conducted a similar study in the United Kingdom. Furthermore, if an 
organization SMI does not set a clear define task and implementation style, workforces do not know which responsibilities they have, disorders may arise, or some events may be forgotten all together thus leading the organization to poor performance (Aaltonen and Ikävalko 2002; Al-Ghamdi 1998; Beer and Eisenstat 2000; Corboy and O'Corrbui 1999).

\subsection{The Mediation Effect of M1 and M2 in the Relationship Between SMI and OP}

The results show in table 5 that the indirect effect of SMI on OP through the M1 and M2 is .673 , positive. Hence, we conclude that the mediator variables M1 and M2 positively influence the relationship between SMI and OP.

Table 5. Standardized Indirect Effects (Group number 1 - Default model)

\begin{tabular}{|l|rrrrrr|}
\hline & WM2 & W & WM1 & SMI & M2 & M1 \\
\hline M2 & .000 & .000 & .000 & .000 & .000 & .000 \\
M1 & .000 & .000 & .000 & .000 & .000 & .000 \\
OP & .000 & .000 & .000 & .673 & .000 & .000 \\
\hline
\end{tabular}

Source: author data field-2020

\section{Testing Hypothesis two and three}

The results shown in table 6 indicate that the path label a: .346 that defines the regression weight between SMI and M1 is positive and significant at p-value p: .001 $<.05$. Additionally, the estimate of the part label d: .374, which defines the regression weigh between M1 and OP, is positive and significant at p-value p: $.008<.05 \%$. According to Hays (2018, page 116) book titled "Introduction to Mediation, Moderation, and Conditional Process Analysis: A Regression-Based Approach," a mediation variable is said to be statically significant if one or both of the paths that define the indirect effect are significant. i.e., the product of the two paths (a.d: .129) is statistically significant and different from zero. Thus, our results show that the two paths label a and $\mathrm{d}$ are both statistically significant and different from zero. Consequently, the study concluded that the variable logical implementation style mediates the relationship between SMI and OP. Hence, hypothesis two is accepted.

In a public organization that opts for logical implementation style (M1) in its strategic management implementation (SMI), when the implementation process goes up to 1 , its organizational performance goes up to .129. Moreover, this finding contradicts the findings of (Andrews, Beynon, and Genc 2017a) who undertook the same study in Welsh local Government and found that a logical implementation style was not associated with public organization performance. Nevertheless, it comes it supports other studies whose concluded their search that the choice of logical implementation style in public organization is associated with a positive organizational performance (Allison and Kaye 2011; Ashworth, Boyne, and Entwistle 2009)]

The results shown in table 6 indicate that the path label c: .820, which defines the regression weight between the SMI and M2, is positive and significant at p-value p: $.001<.05$. Additionally, the estimate that defines the regression weight of the path label e: .663 is 
positive and significant at p-value p: .016 <.05. Referring to Hays (2018, page 116) book titled "Introduction to Mediation, Moderation, and Conditional Process Analysis: A Regression-Based Approach," a mediation variable is said to be statically significant if one or both of the paths that define the indirect effect are significant. i.e., the product of the two paths (c.e: .544) is statistically significant and different from zero. Therefore, the study concludes that the variable incremental implementation style mediates the relationship between SMI and OP. However, the mediation effect of logical implementation style in hypothesis 2, a.d: .129 is weaker than the effect of incremental implementation style c.e: .544 in hypothesis 3, (a.d: .129 <c.e: .544). Hence, hypothesis three is rejected.

Table 6. Standardized Regression Weights of the diagram pathways

\begin{tabular}{|lll|rrrrr|}
\hline \multicolumn{2}{|l|}{ Parameter } & & Estimate & \multicolumn{1}{c|}{ Lower } & \multicolumn{1}{l|}{ Upper } & \multicolumn{2}{c|}{ P } \\
\hline M1 & $<---$ & SMI & .346 & .199 & .484 & .001 & $\mathrm{a}$ \\
M2 & $<---$ & SMI & .820 & .750 & .874 & .001 & $\mathrm{~b}$ \\
OP & $<---$ & SMI & -.308 & -.329 & -.081 & .001 & $\mathrm{c}$ \\
OP & $<---$ & W & -1.235 & -1.595 & -.522 & .001 & $\mathrm{~g}$ \\
OP & $<---$ & WM1 & -.281 & -1.387 & -.183 & .005 & $\mathrm{f}$ \\
OP & $<---$ & M2 & .663 & .077 & .777 & .016 & $\mathrm{e}$ \\
OP & $<---$ & M1 & .374 & .279 & .754 & .008 & $\mathrm{~d}$ \\
OP & $<---$ & WM2 & 1.211 & .272 & 1.313 & .004 & $\mathrm{~h}$ \\
\hline
\end{tabular}

Source: author data field-2020

5.8 The Moderated Mediation Effect of the Implementation Style and Middle Management Effort in the Relationship Between SMI and OP

The study relies on the moderated mediation index's bootstrap results to conclude the moderated mediation's statistical significance (Preacher, Rucker, and Hayes 2007). According to Hayes, in the absence of a p-value, there is a statistical significance if zero is not part of the confidence interval. Thereby, looking at the results in table 7, zero is excluded from the confidence interval of the focal factor logical implementation style (M1), $0 \notin[-0.06,-0.01]$ and $0 \notin[0.013,0.059]$ for the focal factor Incremental implementation style (M2). Consequently, the study concluded that there is a statistical significance of the moderated mediation of both the combination of logical implementation style (M1) with middle management effort (W) and the combination of incremental implementation style (M2) with middle management effort (W)in the relationship between SMI and OP.

Table 7. Index of Moderated Mediation

\begin{tabular}{|c|c|c|c|c|}
\hline Parameter & Estimate & Lower & Upper & P \\
\hline IndModMed & -0.032 & -0.06 & -0.01 & 0.006 \\
\hline IndaModMed & 0.034 & 0.013 & 0.059 & 0.004 \\
\hline
\end{tabular}

Note: $* * *$ Significant at $\mathrm{p}<5 \%$

Source: author data-filled 2020 
Besides, referring to (Hayes 2017, page 316), a conditional effect may be non-significant when the interaction effects are significant; however, Hayes added that the moderator value defining the Johnson-Neyman significance region is significant if the interaction effects are significant. The findings show in table 8 that the estimates of both slopes at mean and 1SD below the mean of the moderator factor W are statistically non-significant (Hayes 2017). Hence, the study concluded that a public organization that opts for M1 in its SMI would result a non-significant $\mathrm{OP}$ when the middle management effort at mean and 1SD below the mean. Consequently, the hypothesis $2 \mathrm{a}$ is rejected.

Table 8. Conditional Indirect effect of W through the focal factor M1

\begin{tabular}{|l|l|l|l|l|}
\hline Parameter & Estimate & Lower & Upper & P \\
\hline lowCIE & 0.074 & -0.006 & 0.158 & 0.072 \\
\hline medCIE & -0.011 & -0.059 & 0.033 & 0.594 \\
\hline highCIE & -0.096 & -0.191 & -0.032 & 0.001 \\
\hline
\end{tabular}

Note: $* * *$ Significant at $\mathrm{p}<5 \%$

Source: author data-filled 2020

However, in table 9 the estimates of the three slopes at mean, 1SD below and 1SD above the mean of the moderator factor $\mathrm{W}$ are all statistically significant (Hayes 2017). Hence, the study concluded that a public organization that opts for M2 in its SMI would generate a positive and significant OP when the middle management effort is at the mean, 1SD below and 1SD above the mean of the moderator factor W. Hence the conditional effect through the focal factor M2 is greater than the conditional effect through the focal factor M1. Consequently, the hypothesis $3 \mathrm{a}$ is rejected.

Table 9. Conditional Indirect effect of $\mathrm{W}$ through the focal factor M2

\begin{tabular}{|c|c|c|c|c|}
\hline Parameter & Estimate & Lower & Upper & P \\
\hline lowCIE & 0.735 & 0.537 & 0.933 & 0.001 \\
\hline medCIE & 0.824 & 0.631 & 1.018 & 0.001 \\
\hline highCIE & 0.913 & 0.702 & 1.122 & 0.001 \\
\hline
\end{tabular}

Note: $* * *$ Significant at $\mathrm{p}<5 \%$

Source: author data-filled 2020

\section{Discussion and Conclusion}

Although public sector organization SMI has been well documented in industrialized western countries and some Asian countries' public sectors within modernization and democratization (R. Andrews, Beynon, and Genc 2017b; Demirkaya 2015, n.d.; Gabris, Golembiewski, and Ihrke 2001; Glaister et al. 2008; Koufopoulos, Lagoudis, and Pastra 2005; Review and Sciences 2018; Rudd et al. 2008), less attention had been paid to the developing countries lacking administrative reform. This study aimed to shed light on the relationship between SMI and public OP in the context of a developing country. Secondly, to present the moderated mediation model that highlighted the intervening factors that potentially influence 
SMI and the OP relationship. The results indicated that a public organization's choice of implementation style in its SMI is an important factor in organizational performance. This finding is consistent with previous research on strategic management implementation and organizational performance (Parsa 1999; Thorpe and Morgan 2007; Wolf and Floyd 2017). Overall, we can conclude that the relationship between strategic management implementation and organizational performance is relevant in the Togolese public sector.

The finding showed that a public organization that opts for a logical implementation style in its SMI generated a positive and significant organizational performance. However, the effect size of those who opt for an incremental implementation style is greater and statistically insignificant than the organization that applies for logical implementation style in their SMI. However, this comes in support of Veliyath \& Shortell (1993), whose finding showed that among 406 United States of America hospitals, those who opt for incremental implementation style in their SMI were more likely to succeed than those applying a more planned approach.

Several scholars argued that middle management effort is crucial for successful strategy implementation ( Westley 1990; Wooldridge and Floyd 1990). Hence, to refine and extend our study's pioneering, as suggested by Aguinis, Edwards, \& Bradley (2017), middle manager effort was included in the model as a moderator factor. As a result, the Johnson-Neyman technique of the moderated mediation shows that at all levels, including mean, 1SD below mean, and 1SD above mean of $\mathrm{W}$, the conditional effect of the focal factor M2 is associated with higher OP than in M1 (Palmer O Johnson and Fay 1950; Palmer Oliver Johnson and Neyman 1936). The finding supports Stewart \& Kringas (2003) conclusion on a case study of six Australian public organization SMI, which show that the more intense is the middle manager effort in an organization that opts for M2 in its SMI, the higher the OP. Hence, the study concluded that SMI associated with better OP heavily relies on the chosen implementation style and the middle management effort in the implementation process.

However, it turned out that while in an organization that opts for M2 in its SMI, management relies on previous experience to guide and adjust the strategy in the implementation process, management in the organization that opts for M1 in its SMI consists of the radical change of management practices. Therefore, an organization that opts for a logical implementation style in its SMI follows prescription and action. Consequently, an organization choice of M1 in its SMI will translate into a better OP if it clarifies the objectives, which are the basis of facilitating the coordination and integration of ongoing activities (Thorpe and Morgan 2007) and its readiness in terms of materials, resources, and high technical experts that able to run planned activities.

Public organization SMI that applies M1, which is associated with OP, is linked with the country economy, finance, and administrative reforms (Andrews et al., 2017a, 2017b; Ashworth et al., 2009; Bryson, 2012; Elbanna et al., 2016; Thorpe et al., 2007). Modernizing the public sector by applying proper reform in the administration is first and foremost to make the public organization more performing in terms of effectiveness, efficiency, and equity and enable it to benefit from good governance (Wazani and Souaf 2017). Hence, this 
provides any country with a modern administration with the necessary skills, aptitudes, educational background, and professional experience at suitable positions capable of supporting its national development plan on economic and social development. Additionally, complex modern organizations' abilities to achieve their goals can be enhanced through management structures and practices that debureaucratize organizational systems (Aucoin 1990).

Additionally, the Togolese Government's idea of budget constraints found its origin in the political arena connected to Niskanen's thesis, which is mainly influenced when budget constraints were a significant concern in many countries. However, this practice led to a dramatic downsizing and a decrease in recruitment in the public sector. Furthermore, in bureaucracy, top positions are occupied by friends and collaborators of political elites. The traditional bureaucracy, dynamic on which the former is considered stronger than the latter in strategic decision making (Kombate and Dong 2018), induce the SMI based on previous experience. Furthermore, a public organization's success that opts for M1 in its SMI might rely on the person's recruitment policy with some critical responsibilities in strategy management implementation. Thus, We deduce that this finding's particularity is founded on its context of a developing country characterized by the absence of reform in the public sector and non-proper public administration practice. Hence, this study's results are different from existing empirical findings in western and Asian modern countries where proper reforms were addressed in the administration, facilitating government national development plans based on radical change.

Furthermore, the findings lie that this study was carried out in a developing country, Togo, with different economic contexts. Knowing that resources are crucial in driving strategic management implementation opts for logical implementation, developing countries like Togo with specific characteristics like weak bureaucracy with lack of resources, technical expertise, and professional development (Kombate \& Dong, 2018) applying radical implementation style. Thus, our study opens the way to other research that could be interested in developing countries.

\section{References}

Aaltonen, P., \& Ikävalko, H. (2002). Implementing strategies successfully. Integrated manufacturing systems.

Abdel-maksoud, A. (2015). The Use of Performance Information in Strategic Decision Making in Public Organizations. (November): 6-7.

Adams, J. M., Harris, A. W., Pinkert, C. A., Corcoran, L. M., Alexander, W. S., Cory, S., ... $\&$ Brinster, R. L. (1985). The c-myc oncogene driven by immunoglobulin enhancers induces lymphoid malignancy in transgenic mice. Nature, 318(6046), 533-538.

Aguinis, H., Edwards, J. R., \& Bradley, K. J. (2017). Improving our understanding of moderation and mediation in strategic management research. Organizational Research Methods, 20(4), 665-685. 
Al-Ghamdi, S. M. (1998). Obstacles to successful implementation of strategic decisions: the British experience. European Business Review.

Alexander, L. D. (1985). Successfully implementing strategic decisions. Long range planning, 18(3), 91-97.

Allard-Poesi, F. (2015). Des méthodes qualitatives dans la recherche en management: Voies principales, tournants et chemins de traverse.

Allison, M., \& Kaye, J. (2011). Strategic planning for nonprofit organizations: A practical guide and workbook. John Wiley \& Sons.

Andrews, R., Boyne, G. A., Meier, K. J., O'Toole Jr, L. J., \& Walker, R. M. (2005). Representative bureaucracy, organizational strategy, and public service performance: An empirical analysis of English local Government. Journal of Public Administration Research and Theory, 15(4), 489-504.

Andrews, R., Beynon, M. J., \& Genc, E. (2017a). Administrative Sciences Strategy Implementation Style and Public Service Effectiveness, Efficiency, and Equity.

Andrews, R., Beynon, M. J., \& Genc, E. (2017). Strategy implementation style and public service effectiveness, efficiency, and equity. Administrative Sciences, 7(1), 4.

Andrews, R., Boyne, G. A., Law, J., \& Walker, R. M. (2009). Centralization, organizational strategy, and public service performance. Journal of Public Administration Research and Theory, 19(1), 57-80.

Andrews, R., Boyne, G. A., Law, J., \& Walker, R. M. (2008). Organizational strategy, external regulation and public service performance. Public administration, 86(1), 185-203.

Andrews, R., Boyne, G. A., Law, J., \& Walker, R. M. (2009). Strategy formulation, strategy content and performance: An empirical analysis. Public Management Review, 11(1), 1-22.

Andrews, R., Boyne, G. A., \& Walker, R. M. (2006). Strategy content and organizational performance: An empirical analysis. Public Administration Review, 66(1), 52-63.

Ashworth, R. E., Boyne, G. A., \& Entwistle, T. (Eds.). (2009). Public service improvement: Theories and evidence. Oxford University Press.

Atuahene-Gima, K. (2005). Resolving the capability-rigidity paradox in new product innovation. Journal of marketing, 69(4), 61-83.

Aucoin, P. (1990). Administrative reform in public management: paradigms, principles, paradoxes and pendulums. Governance, 3(2), 115-137.

Balogun, J. (2003). From blaming the middle to harnessing its potential: Creating change intermediaries. British journal of management, 14(1), 69-83.

Balogun, J., \& Hailey, V. H. (2008). Exploring strategic change. Pearson Education. 
Balogun, J., \& Johnson, G. (2004). Organizational restructuring and middle manager sensemaking. Academy of management journal, 47(4), 523-549.

Bass, B. M. (1985). Leadership: Good, better, best. Organizational dynamics, 13(3), 26-40.

Beer, M., \& Eisenstat, R. A. (2000). The silent killers of strategy implementation and learning. IEEE Engineering Management Review, 28(4), 35-45.

Belderbos, R., Carree, M., \& Lokshin, B. (2004). Cooperative R\&D and firm performance. Research policy, 33(10), 1477-1492.

Berry, F. S., \& Wechsler, B. (1995). State agencies' experience with strategic planning: Findings from a national survey. Public administration review, 159-168.

Boonstra, J. J. (Ed.). (2004). Dynamics of organizational change and learning (p. 512). J. Wiley \& Sons Incorporated.

Boyatzis, R. E. (1982). The competent manager: A model for effective performance. John Wiley \& Sons.

Brislin, R. W. (1970). Back-translation for cross-cultural research. Journal of cross-cultural psychology, 1(3), 185-216.

Bryman, A. (2011). Research methods in the study of leadership. The Sage handbook of leadership, 15-28.

Bryson, J. M. (2012). Strategic Planning and. The SAGE Handbook of Public Administration, 50.

Buick, F., Blackman, D. A., O'Donnell, M. E., O'Flynn, J. L., \& West, D. (2015). Can enhanced performance management support public sector change?. Journal of Organizational Change Management.

Burgelman, R. A. (1994). Fading memories: A process theory of strategic business exit in dynamic environments. Administrative Science Quarterly, 24-56.

Candido, C., \& Santos, S. P. D. (2015). Strategy implementation: What is the failure rate?. Journal of Management \& Organization, 21(02), 237-262.

Caves, R. E., Porter, M. E., Spence, M., \& Scott, J. T. (1980). Competition in the open economy: A model applied to Canada (No. 150). Harvard University Press.

Charlesworth, K., Wilton, P., \& Crozier, G. (2003). Leading change in the public sector: making the difference. London: Chartered Management Institute.

Christensen, C. M. (2006). The ongoing process of building a theory of disruption. Journal of Product innovation management, 23(1), 39-55.

Cole, G. A. (2004). Management theory and practice. Cengage Learning EMEA.

Conger, J. A., \& Kanungo, R. N. (1987). Toward a behavioral theory of charismatic leadership in organizational settings. Academy of management review, 12(4), 637-647. 


\section{Macrothink}

Journal of Public Administration and Governance ISSN 2161-7104 2021, Vol. 11, No. 1

Coram, R., \& Burnes, B. (2001). Managing organisational change in the public sector-Lessons from the privatisation of the Property Service Agency. International Journal of Public Sector Management.

Corboy, M., \& O'Corrbui, D. (1999). The seven deadly sins of strategy. MANAGEMENT ACCOUNTING-LONDON-, 77, 29-31.

Corvo, L., Savignon, A. B., Cepiku, D., \& Meneguzzo, M. (2014). Implementation of strategic and performance management reforms in italian central governments. In Developments in Strategic and Public Management (pp. 121-135). Palgrave Macmillan, London.

Demirkaya, Y. (2015). Strategic planning in the Turkish public sector. Transylvanian Review of Administrative Sciences, 11(SI), 15-29.

Desmidt, S., \& George, B. (2016). Do we see eye to eye? The relationship between internal communication and between-group strategic consensus: A case analysis. Management Communication Quarterly, 30(1), 84-102.

Dewar, R. D., \& Dutton, J. E. (1986). The adoption of radical and incremental innovations: An empirical analysis. Management science, 32(11), 1422-1433.

Dosi, G. (1982). Technological Paradigms and Technological Trajectories: A Suggested Interpretation of the Determinants and Directions of Technical Change. Research policy, $11(3), 147-62$.

Elbanna, S., Andrews, R., \& Pollanen, R. (2016). Strategic planning and implementation success in public service organizations: Evidence from Canada. Public Management Review, 18(7), 1017-1042.

Ferlie, E., \& Ongaro, E. (2015). Strategic management in public services organizations: Concepts, schools and contemporary issues. Routledge.

Floyd, S. W., \& Wooldridge, B. (1992). Middle management involvement in strategy and its association with strategic type: A research note. Strategic management journal, 13(S1), 153-167.

Floyd, S. W., \& Wooldridge, B. (1994). Dinosaurs or dynamos? Recognizing middle management's strategic role. Academy of Management Perspectives, 8(4), 47-57.

Ford, J. D., Ford, L. W., \& D'Amelio, A. (2008). Resistance to change: The rest of the story. Academy of management Review, 33(2), 362-377.

Gabris, G. T., Golembiewski, R. T., \& Ihrke, D. M. (2001). Leadership credibility, board relations, and administrative innovation at the local government level. Journal of public administration research and theory, 11(1), 89-108.

Gault, F. (2010). Innovation strategies for a global economy. International Development Research Centre. 


\section{Macrothink}

Journal of Public Administration and Governance ISSN 2161-7104 2021, Vol. 11, No. 1

Genc, E. (2017). Strategy implementation, organizational culture and performance in Turkish local Government (Doctoral dissertation, Cardiff University).

Giles, W. D. (1991). Making strategy work. Long range planning, 24(5), 75-91.

Glaister, K. W., Dincer, O., Tatoglu, E., Demirbag, M., \& Zaim, S. (2008). A causal analysis of formal strategic planning and firm performance. Management Decision.

Grimshaw, J., Thomas, R., MacLennan, G., Fraser, C. R. R. C., Ramsay, C. R., Vale, L. E. E. A., ... \& Wensing, M. J. P. (2004). Effectiveness and efficiency of guideline dissemination and implementation strategies.

Harari, E., \& Zeira, Y. (1976). Limitations and prospects of planned change in multinational corporations. Human Relations, 29(7), 659-676.

Hayes, A. F. (2017). Introduction to mediation, moderation, and conditional process analysis: A regression-based approach. Guilford publications.

Hays, A. F. (2018). Introduction to Mediation, Moderation, and Conditional Process Analysis: A Regession Approach.

Henderson, R. M., \& Clark, K. B. (1990). Architectural innovation: The reconfiguration of existing product technologies and the failure of established firms. Administrative science quarterly, 9-30.

Hickson, D. J., Miller, S. J., \& Wilson, D. C. (2003). Planned or prioritized? Two options in managing the implementation of strategic decisions. Journal of Management Studies, 40(7), 1803-1836.

Higgs, M., \& Rowland, D. (2010). Emperors with clothes on: The role of self-awareness in developing effective change leadership. Journal of Change Management, 10(4), 369-385.

Höglund, L. (2015). Strategic entrepreneurship: Organizing entrepreneurship in established organizations. Studentlitteratur AB.

Coughlan, D. (2016). Shadows. In Ghost Writing in Contemporary American Fiction (pp. 53-60). Palgrave Macmillan, London.

Hrebiniak, L. G. (2006). Obstacles to effective strategy implementation. Organizational dynamics.

Hussey, D. (1999). Igor Ansoff's continuing contribution to strategic management. Strategic Change, 8(7), 375-392.

Huy, Q. N. (2002). Emotional balancing of organizational continuity and radical change: The contribution of middle managers. Administrative science quarterly, 47(1), 31-69.

Inkpen, A., \& Nandan, C. (1995). The Seeking of Strategy Where It Is Not: Towards a Theory of Strategy Absence. Strategic Management Journal, 16(4), 313-23. 
De Jager, P. (2001). Resistance to change: A new view of an old problem. The futurist, 35(3), 24.

JOHANSON, J. E. (2009). Strategy formation in public agencies. Public Administration, 87(4), 872-891.

Johnson, P. O., \& Fay, L. C. (1950). The Johnson-Neyman technique, its theory and application. Psychometrika, 15(4), 349-367.

Johnson, P. O., \& Neyman, J. (1936). Tests of certain linear hypotheses and their application to some educational problems. Statistical research memoirs.

Judge Jr, W. Q., \& Stahl, M. J. (1995). Middle-manager effort in strategy implementation: A multinational perspective. International Business Review, 4(1), 91-111.

Kalyal, H. J., Berntson, E., Baraldi, S., Näswall, K., \& Sverke, M. (2010). The moderating role of employability on the relationship between job insecurity and commitment to change. Economic and Industrial Democracy, 31(3), 327-344.

Kombate, B., \& Huang, D. (2018). Dictatorship , Bad Governance and Their Impact on Public Need and Social Development : A Comparative Public Administration (CPA) Study on the Evidence of Togo. African Journal of Political Science and International Relations Full (November).

Koufopoulos, D. N., Lagoudis, I. N., \& Pastra, A. (2005). Planning practices in the Greek ocean shipping industry. European Business Review.

Lawrence, J., Ashford, K., \& Dent, P. (2006). Gender differences in coping strategies of undergraduate students and their impact on self-esteem and attainment. Active learning in higher education, 7(3), 273-281.

Leifer, R., McDermott, C. M., O'connor, G. C., Peters, L. S., Rice, M. P., \& Veryzer Jr, R. W. (2000). Radical innovation: How mature companies can outsmart upstarts. Harvard Business Press.

Lewis, J., Williams, A., \& Franklin, B. (2008). Four rumours and an explanation: A political economic account of journalists' changing newsgathering and reporting practices. Journalism practice, 2(1), 27-45.

Madjar, N., Greenberg, E., \& Chen, Z. (2011). Factors for radical creativity, incremental creativity, and routine, noncreative performance. Journal of applied psychology, 96(4), 730.

March, J. G. (1991). Exploration and exploitation in organizational learning. Organization science, 2(1), 71-87.

McCarthy, A., Cleveland, J. N., Hunter, S., Darcy, C., \& Grady, G. (2013). Employee work-life balance outcomes in Ireland: a multilevel investigation of supervisory support and perceived organizational support. The International Journal of Human Resource Management, 24(6), 1257-1276. 
McTaggart, D., \& Janine, O. (2015). Public Sector Reform. Australian Journal of Public Administration, 74(1), 13-22.

Miles, R. E., Charles, C. S., Alan, D. M., \& Henry, J. C. Jr. (1978). Organizational Strategy, Structure, and Process. Academy of management review, 3(3), 546-62.

Miller, S. (1997). Implementing strategic decisions: Four key success factors. Organization studies, 18(4), 577-602.

Mintzberg, H. (2007). Tracking strategies: Toward a general theory. Oxford University Press on Demand.

Mosca, L., Benjamin, E. J., Berra, K., Bezanson, J. L., Dolor, R. J., Lloyd-Jones, D. M., ... \& Zhao, D. (2011). Effectiveness-based guidelines for the prevention of cardiovascular disease in women-2011 update: a guideline from the American Heart Association. Journal of the American College of Cardiology, 57(12), 1404-1423.

Myers, G. L. (2005). A phenomenological study of the leader's experience involving a new information technology. The George Washington University.

Naumann, S., Davis, M., Kaphengst, T., Pieterse, M., \& Rayment, M. (2011). Design, implementation and cost elements of Green Infrastructure projects. Final report, European Commission, Brussels, 138.

Nonaka, I. (1988). Toward middle-up-down management: accelerating information creation. MIT Sloan Management Review, 29(3), 9.

Nunnaly, J. C. (1978). Psychometric theory. McGraw-Hill.

de Oliveira, C. A., Carneiro, J., \& Esteves, F. (2019). Conceptualizing and measuring the "strategy execution" construct. Journal of Business Research, 105, 333-344.

Parsa, H. G. (1999). Interaction of strategy implementation and power perceptions in franchise systems: an empirical investigation. Journal of Business Research, 45(2), 173-185.

Pella, D. A. STRATEGY IMPLEMENTATION PROBLEMS: Discover and overcome factors affecting poor strategy implementation in your organization. Infini.

Piderit, S. K. (2000). Rethinking resistance and recognizing ambivalence: A multidimensional view of attitudes toward an organizational change. Academy of management review, 25(4), 783-794.

Poister, T. H., Edwards, L. H., Pasha, O. Q., \& Edwards, J. (2013). Strategy formulation and performance: Evidence from local public transit agencies. Public Performance \& Management Review, 36(4), 585-615.

Poister, T. H., Pitts, D. W., \& Hamilton Edwards, L. (2010). Strategic management research in the public sector: A review, synthesis, and future directions. The American Review of Public Administration, 40(5), 522-545. 
Pollanen, R., Abdel-Maksoud, A., Elbanna, S., \& Mahama, H. (2017). Relationships between strategic performance measures, strategic decision-making, and organizational performance: empirical evidence from Canadian public organizations. Public Management Review, 19(5), 725-746.

Popadiuk, S., \& Choo, C. W. (2006). Innovation and knowledge creation: How are these concepts related?. International journal of information management, 26(4), 302-312.

Porter, M. E. (1991). Competitive advantage. Planning, 24(4).

Preacher, K. J., Rucker, D. D., \& Hayes, A. F. (2007). Addressing moderated mediation hypotheses: Theory, methods, and prescriptions. Multivariate behavioral research, 42(1), 185-227.

Review, Transylvanian, and Administrative Sciences. (2018). STRATEGIC PLANNING IN THE TURKISH PUBLIC SECTOR * 1 Yüksel DEMIRKAYA. (October).

Rosenberg Hansen, J., \& Ferlie, E. (2016). Applying strategic management theories in public sector organizations: Developing a Typology. Public Management Review, 18(1), 1-19.

Rouleau, L., \& Balogun, J. (2011). Middle managers, strategic sensemaking, and discursive competence. Journal of Management studies, 48(5), 953-983.

Rudd, J. M., Greenley, G. E., Beatson, A. T., \& Lings, I. N. (2008). Strategic planning and performance: Extending the debate. Journal of business research, 61(2), 99-108.

Salkić, I. (2014). Impact of strategic planning on management of public organizations in Bosnia and Herzegovina. Interdisciplinary Description of Complex Systems: INDECS, 12(1), 61-77.

Schaefer, T., \& Guenther, T. (2016). Exploring strategic planning outcomes: the influential role of top versus middle management participation. Journal of Management Control, 27(2-3), 205-249.

Shamir, B., House, R. J., \& Arthur, M. B. (1993). The motivational effects of charismatic leadership: A self-concept based theory. Organization science, 4(4), 577-594.

Sheehan, C. (2005). A model for HRM strategic integration. Personnel review.

Steers, R. M. (1975). Problems in the measurement of organizational effectiveness. Administrative science quarterly, 546-558.

Stewart, J., \& Kringas, P. (2003). Change management-strategy and values in six agencies from the Australian Public Service. Public Administration Review, 63(6), 675-688.

Stewart, J., \& Kringas, P. (2003). Change management - strategy and values in six agencies from the Australian Public Service. Public Administration Review, 63(6), 675-688.

Strickland, A. J., Thompson, A. A., \& Gamble, J. E. (2001). Cases in strategic management. Irwin/McGraw-Hill. 


\section{Macrothink}

Journal of Public Administration and Governance ISSN 2161-7104 2021, Vol. 11, No. 1

Thorpe, E. R., \& Morgan, R. E. (2007). In pursuit of the "ideal approach" to successful marketing strategy implementation. European Journal of Marketing.

Thorpe, E. R., \& Morgan, R. E. (2007). In pursuit of the "ideal approach" to successful marketing strategy implementation. European Journal of Marketing.

Thundiyil, T. (2015). Employee Alignment: A Process for Understanding Individual Changeability (Doctoral dissertation).

Tichy, N. M., \& Bennis, W. G. (2007). Judgment: How winning leaders make great calls. Penguin.

Veliyath, R., \& Shortell, S. M. (1993). Strategic orientation, strategic planning system characteristics and performance. Journal of Management studies, 30(3), 359-381.

Venkatraman, N., \& Ramanujam, V. (1986). Measurement of business performance in strategy research: A comparison of approaches. Academy of management review, 11(4), 801-814.

Venkatraman, N., \& Ramanujam, V. (1987). Measurement of business economic performance: an examination of method convergence. Journal of management, 13(1), 109-122.

Mjidila, B., \& Youssef El Wazani, H. D. R. (2017). Contrôle de Gestion et Performance dans les Organisations Publiques Marocaines: Quelles Spécificités?. European Scientific Journal, 13(1,019,044).

Westley, F. R. (1990). Middle managers and strategy: Microdynamics of inclusion. Strategic management journal, 11(5), 337-351.

Wolf, C., \& Floyd, S. W. (2017). Strategic planning research: Toward a theory-driven agenda. Journal of Management, 43(6), 1754-1788.

Wooldridge, B., \& Floyd, S. W. (1990). The strategy process, middle management involvement, and organizational performance. Strategic management journal, 11(3), 231-241.

Wu, H. (2017, May). Exploring the Origin, Definition and Measurement of Organizational Ambidexterity. In 3rd Annual International Conference on Management, Economics and Social Development (ICMESD 17). Atlantis Press.

\section{Copyright Disclaimer}

Copyright for this article is retained by the author(s), with first publication rights granted to the journal.

This is an open-access article distributed under the terms and conditions of the Creative Commons Attribution license (http://creativecommons.org/licenses/by/4.0/). 